\title{
Natural Dyes from Plants Extract and Its Applications in Indonesian Textile Small Medium Scale Enterprise
}

\author{
Anastasia Wheni Indrianingsih and Cici Darsih \\ Technical Implementation Unit for Chemical Engineering Processes, \\ Indonesian Institute of Sciences (UPT BPPTK LIPI) \\ Gading, Playen, Gunungkidul, Yogyakarta, Phone: +62274-392570, Fax: +62274-391168, \\ email: anastasia_wheni_i@yahoo.com/anas004@lipi.go.id
}

\begin{abstract}
Textile industry is an industry that uses dye a lot. Most of the textile industry use synthetic dyes, mainly because it is easy to obtain, guaranteed availability, provide variety of colors and do not easily fading, but in terms of health and safety, waste of textile dyes is very dangerous because it contains heavy metals such as chromium (Cr), tin (Sn), copper $(\mathrm{Cu})$ and zinc $(\mathrm{Zn})$. These metals can be carcinogenic if it accumulates in the human body. On the other hand, the use of natural dyes from plants extracts has many advantages compared to synthetic dyes, such as safe for human's health and environmental friendly. However there are several drawbacks of natural dyes such as not easily available in the market, not many color choices available and easily fade when compared to synthetic dyes. Therefore, in this paper, we will review the availability of natural dyes, their extraction and its application in Indonesian textile small scale enterprises.
\end{abstract}

Key words: natural dyes, plant extracts, extraction method, textile industry.

\section{Introduction.}

The use of natural dyes for textiles industries has essentially been evolved from many years ago. However, the use of natural dyes was replaced by synthetic dyes slowly because syntetic dyes generally have superior fastness dyeing properties ${ }^{1}$, the colors are more diverse, not easily fading, easy to produce, and the cost is cheaper than natural dyes. Unfortunately, these dyes causes carsinogenity and harmful to the environment ${ }^{2}$. One example of synthetic dyes used in the textile industry is Orange II. This compound has an azo functional group ($\mathrm{N}=\mathrm{N}-$ ) and not easily degraded in the environment. Waste from textile industry also contain heavy metals such as chromium $(\mathrm{Cr})$, tin $(\mathrm{Sn})$, copper $(\mathrm{Cu})$, and zinc $(\mathrm{Zn})$. Because of the negative impact of syntetic dyes to environment and human health, awarness to reuse natural dyes had to be encouraged. Natural dyes can be obtained from plants, animal, and rocks that presence in our environment. Natural dyes are non allergenic, non-toxic and easily degraded so it does not cause environmental pollution ${ }^{3}$. The colors of natural dyes are soothing to eyes, earthly, warm, and high appealing ${ }^{4}$.

\subsection{Problem statement.}

The issue of environmental pollution in industrial batik areas such as Solo and Pekalongan (Central Java, Indonesia) because of synthetic dyes led to the idea of using natural dyes that environmental friendly. Although the presence of natural dyes are very abundant in nature, but many disadvantage of these dyes, such as easy to fade, no availability guaranteed, unvaried of color and a longer process production that required a certain method in extracting natural dyes. Considering the results of a cloth colored with natural dyes will result in more exotic and elegant colors, it is necessary to find out a breakthrough how to popularize natural dyes in textile small and medium scale enterprises.

\section{II.Discussion.}

The availability of natural dyes.

Indonesia has many plants as sources of natural dyes. Several of them that commonly used for dyes are given in Table 1. 
Table 1. Sources of different colored dyes.

\begin{tabular}{|c|c|c|}
\hline Local name (Botanical name) & Parts used & Color \\
\hline Banana (Musa paradidiaca $)^{5}$ & Trunk, petiole, fruit stalk & Brown \\
\hline Kayumanis $^{6}$ & Bark & Brown \\
\hline Mengkudu $^{7,14,15,16,17}$ (Morinda citrifolia Linn) & Root & Red, yellow,brown \\
\hline Tarum ${ }^{7,14}$ (Indigofera tinctoria Linn) & Leaf & Blue \\
\hline Mundu $^{7}$ & Rind & Green \\
\hline Manggis $^{8,9,10,11,60}$ (Garcinia mangostana L) & Rind & Dark red, violet \\
\hline Sirih $^{12}$ (Piper sp.) & Leaf & Brown \\
\hline Pinang $^{12,13}$ (Areca catecha Linn $)$ & Fruit & Dark red \\
\hline Gambir $^{12,17}$ (Uncaria gambir) & Leaf, young branches & Dark red, black \\
\hline Mango ${ }^{18}$ (Mangifera indica Linn) & Leaf & Green \\
\hline Sengon $^{19}$ (Albizia falcataria) & Leaf & Green \\
\hline Intsia bijuga ${ }^{20}$ & Bark & Brown \\
\hline Mahoni $^{21}$ (Switemia mahogany) & Bark & Brown \\
\hline $\operatorname{Teh}^{21}($ Camellia sinensis) & Leaves & Brown \\
\hline Jati $^{2,13,22,23}$ (Tectona grandis Linn) & Leaves, waste of wood & Cokelat muda \\
\hline $\operatorname{Nanas}^{13}$ (Ananas comusus) & Fruit & Red \\
\hline Pinang $^{13}$ (Areca catecha Linn) & Young fruit seed & Dark red \\
\hline Aren $^{13}$ (Arenga pinata Merr) & Fruit & Brown \\
\hline Soga $^{13}$ (Berberis fortuner Lindl) & Root, Bark & Yellow \\
\hline Kunyit $^{13}$ (Curcuma longa L) & Rhizome & Yellow \\
\hline $\operatorname{Jarak}^{13}$ (Recinus commanis L) & Fruit & Green \\
\hline Soga Tingi ${ }^{14}$ (Ceriops candolleana Arn) & Bark & Reddish brown \\
\hline Kunyit $^{14,17}$ (Curcuma domestica) & Rhizome & Yellow \\
\hline Kesumba $^{14,17}$ (Biza orellana $\left.\mathrm{L}\right)$ & Seed & Orange, red \\
\hline Buah naga $^{24}$ (Hylocereus undatus $)$ & Bark & Red \\
\hline $\begin{array}{l}\text { Urcaria gambir-Piper betle Linn leaves, areca } \\
\text { catechw seed (combination) })^{25}\end{array}$ & Leaf, seed & Reddish brown \\
\hline Nilam $^{17}$ ( indofera) & Leaf & Blue \\
\hline Soga jambal $^{50}$ (Pelthophorum ferruginum) & Bark & Brown \\
\hline Jambu biji ${ }^{17}$ (Psidium guajava) & Leaf & Reddish green \\
\hline Secang ${ }^{26}$ (caesalpiria sappan) & Bark & Red \\
\hline Suji $^{27}$ (Dracaena sp.) & Leaf & Green \\
\hline Rumput laut $^{28}$ (sea weed) & Whole & Grayish blue \\
\hline Akasia $^{29}$ (Acacia catechu $)$ & Wood & Brown \\
\hline $\begin{array}{l}\text { Kayu malam, Sasah, Beurih }{ }^{29} \\
\text { (Aporosa frutescens) }\end{array}$ & Wood & Red \\
\hline Plasa $^{29}$ (Butea monosperma) & Flower & Yellow \\
\hline Tegeran $^{29}($ Maclura cochinchinesis $)$ & Wood & Yellow \\
\hline Kawasan,Ki meong $^{29}$ (Mallotus philipines) & Granule fruit & Oranye \\
\hline Katapang $^{29}$ (Terminalia catappa $)$ & Bark, leaf, root, fruit & Black \\
\hline Tarum akar $^{29}$ (Marsdenia tinctoria) & Leaf & Blue \\
\hline Noja $^{29} \quad$ (Perstrophe bivolvis) & Leaf, young branches & Red \\
\hline $\operatorname{Jirak}^{29}($ Symplocos $)$ & Bark & Yellow \\
\hline
\end{tabular}

\section{Extraction Methods.}

Extraction process is used to extract the dye from the plants. The materials generaly are prepared in small pieces, dried, and powdered. The extraction process commonly used are : a. Cold percolation. 
This process was done using several solvent such as water, ethanol or combination ${ }^{30}$. It takes form hours to days of maceration.

b. Hot percolation.

Hot percolation was done in soxhlet extractor using organic solvent such as hexane, benzene, chloroform and methanol in an increasing polarity ${ }^{30,31,56,58}$. It also can be done simply by heating the sample in a solvent or combination of solvents with certain temperature $10,11,26,29,31$ or till boiling. Reflux also be used a lot in the process of extraction.

c. Combination of cold and hot percolation.

Ussualy in this method, dried samples were crushed and soaked in water separately for 4 to 24 hours followed by boiling for 30 min-1 hour ${ }^{3,32,33}$.

d. Aqueous method.

This process use water as the solvent for extraction. Samples of plants that have been powdered and dried then boiled or heated to a certain temperature in the water for certain time ${ }^{34,35,36,37,55}$. This method is the common method for extraction process because it is the most economical and convenient process although sometimes the yield and quality of the dye extract obtained is less.

e. Acid process.

Extraction process is done by using acid such as $\mathrm{HCl}^{37,38}$, formic acid ${ }^{39}$, oxalic acid ${ }^{40}$, glacial acetic acid ${ }^{57}$ etc in the solvents composition. This process can be done at room temperature till heated to a certain temperature.

f. Alkali process.

Extraction process is done by using alkali such as saturated $\mathrm{Na}_{2} \mathrm{CO}_{3}{ }^{41}, \mathrm{NaOH}^{37}$, etc in the solvents composition. This process can be done at room temperature till heated to a certain temperature.

g. Super Critical Fluid Extraction.
This process is a further advancement of making significant step over the use of conventional solvent extraction technology ${ }^{37}$. It uses $\mathrm{CO}_{2}$ as extraction media. It is non-hazardous and subject to minimum waste generation.

h. The Microwave Assisted Extraction Technology

This process is a high-speed method used to selectively target compounds from various raw materials ${ }^{37}$. The technology uses a microwave applicator as the energy source during solvent extraction leading to the following advantages: faster processing, better yield and quality and lower energy consumption.

i. Ultrasonic extraction.

This process use ultrasound equipments to extract the natural dyes ${ }^{42}$.

\section{Bonding (Chemistry)}

Natural dyes can not attach directly to the fabric to produce colors. It need a bridge to connect the dye to fabric. In dyeing cloth, the bridge is known as mordant ${ }^{45}$. Mordant promote the binding of dyes to fabric by forming a chemical bridge from dye to fiber that insuloble in water. This is improving the staining ability of dye a long with increasing its fastness properties ${ }^{46}$. The mordant is usually in the form of salt ${ }^{47,48}$. Mordant acts as an electron acceptor in coordination bonds between fabrics and dyes. The use of mordant in dyeing process will give different colors on the fabric.

The presence of functional groups in the dyes cause the dyes can bind to the metal ion. Generally two hydroxyl groups or a hydroxyl group with carbonyl, nitroso or azo group in adjacent positions are responsible for coordination ${ }^{49}$. Some examples of dye bond with the metal ion and nylon are as follows:

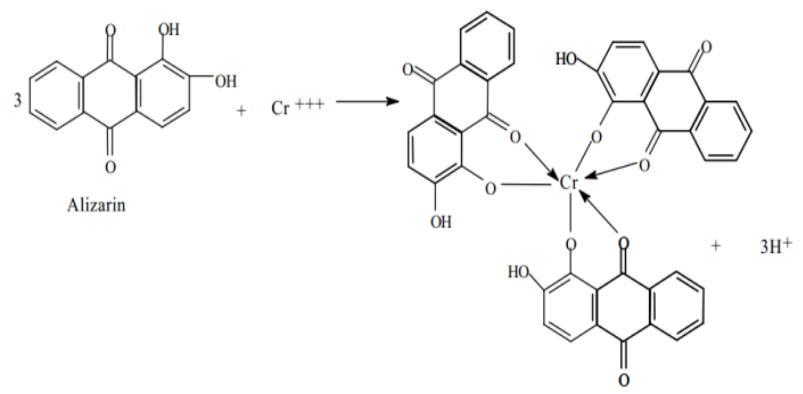

Figure 1. Formation of alizarin-chromium complexes ${ }^{49}$

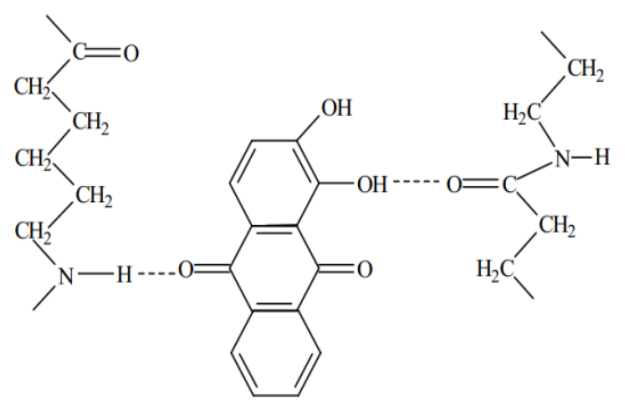

Figure 2. Hydrogen bonded dye interaction with Nylon- $6{ }^{49}$.

Example of the bind of $\mathrm{Fe}$ mordant with acacetin is

given in Figure 3. 


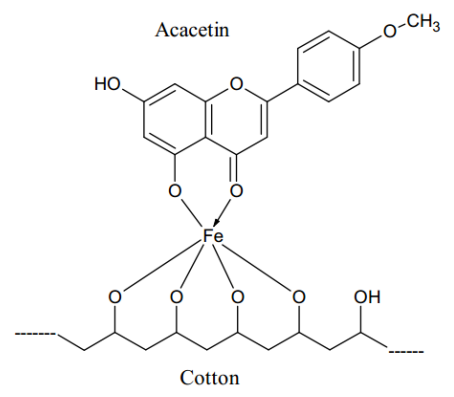

Figure 3. Fe mordant as a bridge between dyes and fibre ${ }^{50}$.

\section{Application in Indonesian textile small medium scale enterprises (SMEs).}

There are many textile small medium scale enterprises in Indonesia, especially that known as batik industry. Batik has become a trade mark of traditional cloth from Indonesia and widely used as a national uniform in Indonesia. Batik industry in Indonesia is growing rapidly due to the increasing needs of batik in local and abroad. This can be indicated by the total of batik industry and its product from years to years. For example in 2009, there were 24.079 units of batik industry textile small medium scale enterprises with 47.161 workers and in 2010 that number increased, that is 20.966 units with 48.732 workers $^{51}$. Production of batik reached approximately Rp 648.94 billion in 2009 and Rp 732.67 billion in $2010^{59}$.

Batik industry use sintetic and natural dyes in dyeing process. There are several batik of small and medium scale enterprises (SMEs) in Indonesia that respond positively to the use of natural dyes for coloring, such as: 1. Cirebon Regency

There is a SME in Trusmi, Cirebon that is Mr. Kama batik $^{52}$. This SME has "mega mendung" motif on its batik and using natural and sintetic dyes. Problems that faced by SMEs batik are there is no research in natural dyes in Cirebon, limited of raw materials that can be used to natural dyes in the local area, and limited network marketing.

2. Bantul Regency

Yogyakarta is famous in its batik. One of the place that have many batik SMEs is Bantul regency. In the Wukirsari village, there is Giriloyo batik ${ }^{53}$. This SME use natural dyes in dyeing process. It use brown color from combination of soga (Pelthophorum ferruginum), tingi (Ceriops tagal), tegeran (Maclura cochinchiinesis), and others.

In Ngentak, Pelem, Baturetno, Banguntapan, ${ }^{54}$ Bixa batik was established to fulfill the demand of batik market in abroad that use natural dyes. Their products have been exported to Japan, Canada, America, and South Korea.

In Pajimatan, Girirejo, Imogiri there is also a batik SME that already use natural dyes. Mr. Slamet, the owner of Tyas batik said that natural dyes production need more time and energy. The raw material commonly used for natural dyes are taken from leaves, sticks, and fruits in the environment. The colors obtained are black, brown, and yellow.

\section{Tarakan City ${ }^{52}$}

Batik SMEs in this city has comitment to implement the cleaner production concept and use natural dyes in its process, cultivate plants that have potency for natural dyes resources, and expand the land in each SME area to cultivate those plants.

4. Galur District, Kulon Progo, Yogyakarta ${ }^{53}$

Alis Widodo batik SME use natural dyes for his business. Sogan color (brown) was obtained from bark of mahogany. While black is the result of combination sogan and blue. Blue color is produced from indigo plant, that is known as Indigofera tintoria leaves. Fermentation of indigo leaves in water which undergoes oxidation after mixing with limestone can produce blue color. There are another dyes plants that be used in his process that are mango leaves and areca to produce light green and red color.

5. Probolinggo Regency ${ }^{14}$

There are 36 species of plants that used as natural dyes, which included in the 27 family. Mahogany (Swietenia mahagoni (L.) Jacq.) tree and tarum (Indigofera tintoria L.) are the most widely used as natural dyes. The most commonly used are leaves. The color resulted from that plants are brown, red, green, blue, orange, yellow, black, beige, purple, pink, and gray. The extracting process of the plants to obtain natural dyes is by boiling in water. Raw material source as natural dyes obtained from several ways such as buying as of $49 \%$, cultivate by themself as of $25 \%$, of wild plants as of $23 \%$, and waste as of $3 \%$.

\section{Pekalongan Regency}

Pekalongan also famous for its batik SMEs besides Yogyakarta dan Solo. Mr. Harris Riadi with his new inovation of "Batik Mbeling" use sea weed to obtain bluish-grey color to dyeing his batik ${ }^{28}$.

7. Alor Island, East Nusa Tenggara ${ }^{54}$

SMEs in Alor Island, East Nusa Tenggara, use indigineous plants to color their thread. The green color is produced from the leaves of papaya, yellow from turmeric and black from indigo leaves. There are around 30 kinds of colors can be produced from plants that live in Alor Island. The process of staining uses traditional ways such as frying on the pan ${ }^{33}$.

Extraction methods that is used to get pigments color from the plants depend on the nature of the pigments. The most of extraction methods that used in batik industry/ SMEs in Indonesia is aqueos method (extraction using water as solvent). This method is easy and everyone can do it. Moreover, the solvent is cheap and easily obtained. 
The disadvantage of this method is the natural dye extract easy to mold if it is not added with preservative chemical and didn't store correctly. Because of that, the extract must be heated before use in dyeing process. However, if the natural dyes extracs will be store in pasta form, the solvent should be evaporate with certain technique. One of the technique that ussually be used is drying in oven. Unfortunately, not all batik SMEs in Indonesia has an oven, and it becomes one of the problems in SMEs.

The participation is needed in all aspects of the development of natural dyes. The government should participate in the development of this batik SMEs, such as culture and tourism department have to promote batik with natural dyes, the banking sector should help the credit and financial sector, the Department of Agriculture and Forestry help to cultivate indigineous dyes plants and other sector (universities and other research institutions) conduct a more in-depth research on natural dyes.

\section{V.Conclusion.}

Different types of indigenous plants produce natural dyes in Indonesia. By using the appropriate extraction method, it is expected to obtain natural dyes extracts having high quality that can be used by batik/textile SMEs in Indonesia. The role of the government in encouraging batik SMEs to use natural dyes should be enhanced, such as provide credit and financial aid, marketing assistance, and give an award for SMEs that running an environmental friendly industry.

\section{VI.References.}

Haji, Aminoddin, 2010, Functional dyeing of wood with natural dye extracted from Berberis vulgaris wood nad Rumex Hymenosepolus root as biomordant; Iran J. Chem. Eng. , Vol. 29, No. 3.

I.Ruwana, 2008, Pengaruh Zat Fiksasi Terhadap Ketahanan Luntur Warna Pada Proses Pencelupan Kain Kapas Dengan Menggunakan Zat Warna Dari Limbah Kayu Jati, Teknologi dan Kejuruan, Vol. 1 No. 1, 75-86.

A. Inayat, S. R. Khan, A. Waheed, F. Deeba, 2010, Applications Of EcoFriendly Natural Dyes On Leather Using Different Modrants, Proc. Pakistan Acad. Sci., 47(3):131-135.

A. Moiz, M. A.Ahmed, N. Kausar, K. Ahmed, M. Sohail, 2010, Study the effect of metal ion on wool fabric dyeing with tea as naural dye, Journal of Saudi Chemical Society, 14, 69-76,

E. Kwartiningsih, A. Andani, S. Budiastuti, A. Nugroho, F. Rahmawati, 2010, Pemanfaatan Getah Berbagai Jenis dan Bagian dari Pohon Pisang Sebagai Zat Pewarna Alami Tekstil, Ekuilibrium, Vol. 9 No. 1, 5-10.

http://berita.liputan6.com/read/136792/akar-tumbuhanbisa-menjadi-pewarna-kain-batik. http://www.indonesia.travel/id/destination/512/sumenep/a rticle/103/batik-madura-menemukan-kain-batikgentongan-yang-cerah-dan-unik.
F. Ulfah, 2007, Ekstraksi dan Karakterisasi Zat Warna Dari Kulit Buah Manggis (Garcinia mangostana L) Serta Uji Potensinya Sebagai Pewarna Tekstil, Skripsi, Universitas Negeri Malang.

Asep M. Samsudin, Khoiruddin, Ekstraksi, Filtrasi Membran dan Uji Stabilitas Zat Warna Dari Kulit Manggis (Garcinia mangostana), www.eprints.undip.ac.id/763/

F. M. Andini, 2011, Laporan Tugas Akhir, Pengujian Stabilitas Zat Warna Kulit Manggis ( Gracinia mangostana L ) Dengan Spektrofotometer, Universitas Diponegoro.

E. Kwartiningsih, D.A. Setyawardhani, A. Wiyatno, A. Triyono, 2009, Zat Pewarna Alami Tekstil dari Kulit Buah Manggis, Ekuilibrium, Vol. 8, No. 1,41 -47.

N. W. Bogoriani, 2010, Ekstraksi Zat Warna Alami Campuran Biji Pinang, Daun Sirih, Gambir dan Pengaruh Penambahan KmnO4 Terhadap Pewarnaan Kayu Jenis Albasia, Jurnal 4 (2), 125134.

www.plh_smk.or.id/jasa_pewarna.html.

http://lib.uin-malang.ac.id/thesis/chapter_ii/07620010mudrika.ps.

Rendra Yuliastrika, 2008, Skripsi, Ekstraksi dan Karakterisasi Zat Warna Dari Kulit Akar Mengkudu (Morinda citrifolia L.) dan Uji Potensinya Sebagai Pewarna Tekstil, Universitas Negeri Malang.

Hamid, Tilani, Muhlis, Dasep, 2005, Perubahan sifat fisika dan kimia kain sutera akibat pewarna alami kulit akar pohon mengkudu (Morinda citrifolia), Jurnal teknologi, Fakultas Teknik Universitas Indonesia, Vol.19 No.2, 163-170.

http://grosirpekalongan.blogspot.com/2009/05/pengetahu an-dasar-pewarna-alam-batik.html.

D. Suheryanto, 2010, Optimalisasi Celupan Ekstrak Daun Mangga Pada Kain Batik Katun Dengan Iring Kapur, Prosiding, Seminar Rekayasa Kimia dan Proses, ISSN : 1411-4216.

D. Kusriniati, E. Setyowati, U. Achmad, 2008, Pemanfaatan Daun Sengon (Albizia Falcataria) Sebagai Pewarna Kain Sutera Menggunakan Mordan Tawas Dengan Konsentrasi Yang Berbeda, Teknobuga, Vol. 1 No.1.

U.R. Indah, I. K. Murwani, D. Presetyoko, 2010, Optimasi Ekstraksi Zat Warna Pada Kayu Intsia bijuga dengan Metode Pelarutan, Prosiding Tugas Akhir Semester Ganjil 2009/2010, Prosiding Kimia FMIPA - ITS.

S. Ramadhan, T. Husniati, W.A. Salis, Y. Istiqomah, 2009, Pembuatan Zat Warna Alam Menggunakan Daun Teh (Camellia sinensis), Proposal, Sekolah Tinggi Teknologi Tekstil Bandung.

A. Mahayana, Pengaruh Pelarut dan Waktu Ekstraksi pada Isolasi Zat Warna dari Daun Jati, Jurnal Kimia dan Teknologi, ISSN $0216-163 \mathrm{X}$, http://124.40.250.43/jurnalteknik/images/files/Nask ah\%20Argoto(1).pdf.

O. Siti R., A. Nawawi, R. Emran, Studi Pendahuluan Produksi Zat Warna Alami Daun Jati (Tectona grandis L. f.), http://bahan-alam.fa.itb.ac.id. 
R. Wulandari, 2011, Laporan Tugas Akhir, Pengujian Zat Warna Dari Kulit Buah Naga Dengan Menggunakan Spektrofotometer Optima SP-300.

N.W. Bogoriani, A. A. Bawa Putra, 2009, Perbandingan Massa Optimum Campuran Pewarna Alami Pada Kayu Jenis Akasia (Acacia leucopholea), Jurnal Kimia 3 (1), 21-26.

Murbantan, A. Mustafa, M. Rosjidi, H. Saputra, Proses Ekstraksi dan Powderisasi Zat Warna Alam, Prosiding Seminar Peningkatan Daya Saing Nasional Melalui Pemanfaatan Sumber Daya Alam Untuk Pengembangan Produk dan Energi Alternatif, ISSN 1410-9891.

T.F. Hutajulu, E.S. Hartanto, Subagja, 2008, Proses Ekstraksi Zat Warna Hijau Khlorofil Alami Untuk Pangan dan Karakterisasinya, Jurnal Riset Industri, Vol. 2, No.1, 44-55.

]http://www.pekalongankota.go.id/index.php?option=co $\mathrm{m} \_$content\&view $=$article\&id $=853$ : warna-alami-darirumput-laut\&catid=82:terkini.

B. Sobandi, Zat Warna Alam.

S. Oberoi, L. Ledwani, 2010, Isolation and characterization of new plant pigment along with three known compounds from Butea monosperma petals, Arch. Appl. Sci. Res., 2 (4):68-71.

H. Goodarzian, E. Ekrani, Extraction of Dye from madder Plant (Rubia tictorium L.) and Dyeing of Wool, World Appl. Sci. J., 9(4), 434-436, 2010.

P. A. G. Wanyama, B. T. Kiremire, P. Ogwok, J. S. Murumu, 2010, Characterization of color from some dye-yielding plants in Uganda, Afr. J. Pure Appl. Chem., Vol. 4(10): 233-239.

W.Y. W. Ahmad, N. Saim, M.A.M.Nor, M.I.A. Kadir, M. R. Ahmad, Extraction of Natural Dyes From Melastoma malabathricum L. And Dicranopteris linearis

Plant, http://www.biotek.gov.my/nbs2010/program/poster/ ind/abstract/C23\%20Wan\%20Yunus\%20Wan\%20A hmad\%20UiTM.pdf.

P. Mishra, V. Patni, 2011, Extraction and Application of Dye Extracted From Eriophyid Leaf Galls of Quercus leucotrichophora- A Himalayan Bluejack Oak, African Journal of Biochemistry Research Vol. 5(3), 90-94.

N. Grover, V. Patni, 2011, Extraction and Application of Natural Dye Preparations From The Floral Parts of Woodfordia fruticosa (Linn.) Kurz, Indian Journal of Natural Products and Resources Vol. 2(4), 403408.

D. Jothi, 2008, Extraction of Natural Dyes From African Marigold Flower (Tagetes Ereecta L) For Textile Coloration, Autex Research Journal, Vol. 8, No2, June 2008, 49-53.

www.dsir.gov.in.

Wouters J, Verhecken A (1989) Stud Conserv 34:189 200.

Zhang X, Laursen RA (2005) Anal Chem 77:2022- 2025.

Guinot P, Andary C (2006) Molecules involve d in the dyeing process with flavonoids. Oral presentation, 25th Meeting of Dyes in History and Archaeology, Suceava, Romania.
M. M Alam, M. L. Rahman and M. Z. Haque, Extraction of Henna Leaf Dye and its Dyeing Effects on Textile Fibre, Bangladesh J. Sci. Ind. Res. 42(2), 217-222, 2007.

V.Sivakumar, J. L. Anna, J. Vijayeeswarri, G. Swaminathan, 2009, Ultrasound assisted enhancement in natural dye extraction from beetroot for industrial applications and natural dyeing of leather, Ultrasonics Sonochemistry, 16, 782-789.

Surowiec I, Orska-Gawrys J, Biesaga M, Trojanowicz M, Hutta M, Halko R, Urbaniak-Walczak K, 2003, Anal Lett 36:1211-1229.

H. Schweppe, 1979, J. Am. Inst. Conserv. 19:14-23.

R. Siva, 2007, Status of natural dyes and dye-yielding plants in India; Current Science, Vol. 92 No. 7.

S. Janhom, P. Grittiths, R. Watanesk, S. Watanesk, 2004, Enhancement lac dye adsorption on cotton fibres by polyethyleneimine, Dyes and Pigments, 63, 231-237.

P. Kongkachuchay, A. Shitangkoon, N. Chinwongamoin, 2002, Studies on Dyeing of Silk Yarn with Lac Dye : Effect of Mordants an Dyeing Conditions, Science Asia 28, 161-166.

Kulkarni S.S., Gokhale A.V, Bodake U.M, Pathade G.R., 2011, Cotton Dyeing with Natural Dye Extracted from Pomegranate (Punica granatum) Peel, Universal Journal of Environmental Research and Technology, Volume1, Issue 2: 135-139.

P. S. Vankar, 2000, Chemistry of Natural Dyes, Resonance, October, 73-80.

S. Ali, 2007, Evaluation of Cotton Dyeing With Aqueous Extracts of Natural Dyes From Indigenous Plants, Dissertation, Dept. Of Chemistry, Univ. Of Agriculture, Faisalabad, Pakistan.

http://www.kemenperin.go.id/jawaban.php?id=437825091.

http://ppbn.or.id.

http://batiktulisgiriloyo.blogspot.com/.

http://berita.liputan6.com/read/146108.

H. Zhou, L. Wu, Y. Gao, T. Ma, 2011, Dye-sensitized Solar Cells Using 20 Natural Dyes As Sensitizers, Journal of Photochemistry and Photobiology A: Chemistry 219, 188-194.

Kulkarni S. S., Bodake U. M., Pathade G. R., Extraction of Natural Dye from Chili (Capsicum Annum) for Textile Coloration, Universal Journal of Environmental Research and Technology, $2011 \mathrm{Vol}$ 1, 58-63.

P. Suabjakyong, S. Romratanapun, N. Thitipramote, 2011, Extraction of Natural Histological Dye from Black Plum Fruit (Syzygium cumini), Journal of the Microscopy Society of Thailand 4 (1), 13-15.

H. U. Jan, Z. K. Shinwari, K. B. Marwat, 2011, Influence of Herbal Dye Extracted From Dry Wood of Indigenous Berberis Pachyacantha Kochine In Plant Histological Staining, Pak. J. Bot., 43(5): 2597-2600. http://www.kemenperin.go.id/artikel/871/Nilai-ProduksiBatik-Bisa-Capai-Rp1-T.

D. Malik, Prosiding Seminar Peningkatan Daya Saing Nasional Melalui Pemanfaatan Sumber Daya Alam Untuk Pengembangan Produk dan Energi Alternatif, Aplikasi Praktis Zat Warna Alam Dari Ekstrak Kulit 
Buah Manggis Untuk Pewarnaan Bahan Kapas, ISSN 1410-9891. http://www.ukmptk.com/ artikel/bisnis/berkat-batikraup-omzet-miliaran-rupiah-bulan http://bantulbiz.com/id/berita_baca/idb-108.html. 